\title{
Extraordinary Diversity of Chemosensory Receptor Gene Repertoires Among Vertebrates
}

\author{
P. Shi and J. Zhang
}

\begin{abstract}
Chemosensation (smell and taste) is important to the survival and reproduction of vertebrates and is mediated by specific bindings of odorants, pheromones, and tastants by chemoreceptors that are encoded by several large gene families. This review summarizes recent comparative genomic and evolutionary studies of vertebrate chemoreceptor genes. It focuses on the remarkable diversity of chemoreceptor gene repertoires in terms of gene number and gene sequence across vertebrates and the evolutionary mechanisms that are responsible for generating this diversity. We argue that the great among-species variation of chemoreceptor gene repertoires is a result of adaptations of individual species to their environments and diets.
\end{abstract}

\section{Introduction}

Chemosensation is responsible for the detection of chemicals in the external environment and is essential for an organism's survival and reproduction (Prasad and Reed 1999). Chemosensation originated very early in evolution, as even bacteria can respond to chemical changes in the environment. This type of chemoreception is known as the general chemical sense and is universal among organisms (Smith 2000). In this review, however, we will not study this general chemical sense. Instead, we will focus on two types of chemoreception that are animal-specific: olfaction (detection of odorants and pheromones) and gustation (detection of tastants). Owing to space limitations, we will only discuss vertebrates. It is widely thought that chemoreception plays multiple important roles in a vertebrate's daily life, including food detection and discrimination, toxin and predator avoidance, mating, and territoriality (Prasad and Reed 1999). Vertebrate chemosensory

P. Shi $(\bowtie)$

State Key Laboratory of Genetic Resources and Evolution, Kunming Institute of Zoology, The Chinese Academy of Sciences, Kunming 650223, China

email: ship@mail.kiz.ac.cn 
systems include the olfactory system, which detects odorants and pheromones in the nasal cavity, and the gustatory system, which perceives different tastants with the tongue. Within the olfactory system there are two anatomically distinct organs: the main olfactory epithelium (MOE) and the vomeronasal organ (VNO) (Dulac and Torello 2003). It was initially thought that the MOE and the VNO have distinct functions, as the MOE is largely responsible for the detection of ordinary odorants, while the VNO detects pheromones (Dulac 1997; Buck 2000), although the current view is that the two systems can both detect odorants and pheromones. For the gustatory system, the tongue can perceive five basic tastes: sour, salty, bitter, sweet, and umami (Kinnamon and Margolskee 1996; Lindemann 2001). Among them, the sweet and umami tastes can influence appetitive reactions and generally reflect the identification of nutrients, whereas the bitter taste may result in aversion and therefore is a defensive mechanism against ingestion of toxins (Herness and Gilbertson 1999).

The ability of the chemosensory system to detect a diverse array of chemicals is mediated by the distinct chemoreceptors encoded by several gene families. The characterization of chemoreceptor genes started in 1991 with the Nobel-prize-winning discovery of 18 rat odorant receptor (OR) genes (Buck and Axel 1991). ORs have seven transmembrane domains and belong to the G-protein-coupled receptor (GPCR) family A. It has been proposed that the potential odorant-binding pocket is formed by the third, fifth, and sixth transmembrane domains (Emes et al. 2004). OR genes have no introns and the coding region of each gene has about 1,000 nucleotides. They are mainly expressed in sensory neurons of MOEs. It is widely accepted that a single OR allele is expressed in each olfactory sensory neuron, known as the "one neuron-one gene" hypothesis (Mombaerts 2004). Recently, trace amine-associated receptors (TAARs) were demonstrated to be the second class of chemosensory receptors in the MOE (Liberles and Buck 2006). TAARs and ORs share many features, including the gene structure and expression profile (Liberles and Buck 2006), but TAARs and ORs are not coexpressed in any neurons (Liberles and Buck 2006).

Two distinct superfamilies of GPCRs, V1Rs and V2Rs, have been identified as vomeronasal receptors (Dulac and Axel 1995; Herrada and Dulac 1997; Matsunami and Buck 1997; Ryba and Tirindelli 1997). Like ORs and TAARs, V1R genes have intronless coding regions. They are coexpressed with the $\mathrm{G}$-protein subunit $\mathrm{G}_{\alpha \mathrm{i} 2}$ in sensory neurons whose cell bodies are located in the apical part of the vomeronasal epithelium (Dulac and Torello 2003; Mombaerts 2004). In contrast, V2Rs are characterized by the presence of a long, highly variable N-terminal domain. They are encoded by multiexon genes expressed in $\mathrm{G}_{\alpha 0}$-positive neurons whose cell bodies are located basally in the vomeronasal epithelium (Dulac and Torello 2003; Mombaerts 2004). Neurons expressing V1R and V2R receptors project to the anterior and posterior accessory olfactory bulb, respectively, where they form multiple glomeruli in spatially conserved domains (Dulac and Torello 2003). Interestingly, the four olfactory-system-related gene families (OR, TAAR, V1R, and V2R) are not evolutionarily related, although all of them belong to GPCRs. 
In mammals, T1Rs and T2Rs have been identified as sweet/umami and bitter taste receptors, respectively. In additional to the distinct physiological functions, T1Rs and T2Rs also differ in expression pattern and molecular structure. Multiple T2Rs are coexpressed in individual cells that also express $\alpha$-gustducin, a G-protein subunit (Adler et al. 2000; Nelson et al. 2001; Behrens et al. 2007). T1Rs, on the other hand, are not coexpressed with $\alpha$-gustducin. T1R1 and T1R2 are expressed in distinct taste receptor cells, but they are always coexpressed with T1R3. Consistent with the expression feature, T1R3 forms a heteromeric receptor with T1R1 to detect L-amino acids and monosodium L-glutamate, which is the taste of umami, or combines with T1R2 to broadly respond to sweet tastants (Nelson et al. 2001; Li et al. 2002). Different from T1R genes, which contain multiple introns, $\mathrm{T} 2 \mathrm{R}$ genes are intronless in the coding region. T1R proteins are characterized by a long N-terminal extracellular domain, whereas T2Rs have a short N-terminal domain (Hoon et al. 1999; Adler et al. 2000; Meyerhof 2005).

Chemoreception varies substantially among vertebrates, probably because of the tremendous diversity of chemical stimuli in the external environments of various species. We summarize in this review recent comparative genomic studies on the variation of gene number and gene sequence of chemoreceptor gene families among vertebrates. We also discuss the genetic mechanisms and evolutionary consequences of these features with an emphasis on the adaptive diversification of chemosensory receptor genes.

\section{Chemoreceptor Gene Families in the Main Olfactory System}

\subsection{The OR Gene Family - the Largest Gene Family in Mammals}

The OR gene family is known to be the largest gene family in the vertebrate genome. Since the original discovery in 1991 (Buck and Axel 1991), OR genes have been partially cloned from many vertebrates (Mombaerts 1999). The first near-complete OR gene repertoire was not unveiled until 2001, when the draft human genome sequence became available (Glusman et al. 2001; Zozulya et al. 2001). Since then, the complete OR gene repertoires have been characterized in several major vertebrate lineages for which the genome sequences are available, including teleosts (pufferfish, fugu, and zebrafish), amphibians (frog), birds (chicken), and mammals (human, mouse, rat, dog, cow, opossum, and platypus) (Alioto and Ngai 2005; Niimura and Nei 2005, 2006, 2007; Grus et al. 2007). As shown in Table 1, the number of functional OR genes varies greatly among species, ranging from 44 genes in fugu to over 1,200 genes in rat (Alioto and Ngai 2005; Niimura and Nei 2005, 2007). The gene number is substantially smaller in fishes than in birds and mammals, while that of the amphibian frog appears to be in the middle. The largest known fish functional OR gene repertoire is in zebrafish, with at least 102 genes (Alioto and Ngai 2005; Niimura and Nei 2005). 
However, this number is still much lower than that in mammals, even when we consider only human and platypus, two mammals that are believed to have reduced main olfactory sensitivity (Niimura and Nei 2006; Grus et al. 2007). Variation in the number of functional OR genes also exists among species of the same class. In mammals, the smallest numbers are 387 and 262, found in human and platypus, respectively (Young and Trask 2002; Niimura and Nei 2003, 2007 Malnic et al. 2004; Grus et al. 2007), while the largest numbers are 1,207 and 1,188, for rat and opossum, respectively (Niimura and Nei 2007).

Phylogenetic analysis helps us understand the evolutionary history and mechanism of the extraordinary diversity of the vertebrate OR gene family. The phylogenetic tree shows that the OR gene family can be classified into two groups, type 1 and type 2 (Fig. 1a). The divergence of these two types predated the split between jawed vertebrates and jawless vertebrates (Fig. 1b). The phylogenetic analysis revealed at least

Table 1 Sizes of chemosensory receptor gene repertoires in vertebrates

\begin{tabular}{lllllll}
\hline Species & OR & TAAR & V1R & V2R & T1R & T2R \\
\hline Human & $387(415)^{\mathrm{a}}$ & $6(3)^{\mathrm{b}}$ & $5(115)^{\mathrm{c}}$ & $0(20)^{\mathrm{d}, \mathrm{e}}$ & $3^{\mathrm{f}}$ & $25(11)^{\mathrm{f}}$ \\
Mouse & $1,035(356)^{\mathrm{g}}$ & $15(1)^{\mathrm{b}}$ & $191(117)^{\mathrm{h}}$ & $121(158)^{\mathrm{d}, \mathrm{e}}$ & $3^{\mathrm{f}}$ & $35(6)^{\mathrm{f}}$ \\
Rat & $1,207(560)^{\mathrm{g}}$ & $17(2)^{\mathrm{b}}$ & $117(72)^{\mathrm{h}}$ & $79(142)^{\mathrm{d}, \mathrm{e}}$ & $3^{\mathrm{f}}$ & $37(5)^{\mathrm{f}}$ \\
Dog & $811(289)^{\mathrm{g}}$ & $2(2)^{\mathrm{b}}$ & $8(33)^{\mathrm{c}, \mathrm{i}}$ & $0(9)^{\mathrm{d}, \mathrm{e}}$ & $3^{\mathrm{f}}$ & $15(5)^{\mathrm{f}}$ \\
Cow & $970(1,159)^{\mathrm{g}}$ & $17(9)^{\mathrm{b}}$ & $40(45)^{\mathrm{c}, \mathrm{i}, \mathrm{d}}$ & $0(16)^{\mathrm{d}, \mathrm{e}}$ & $3^{\mathrm{f}}$ & $12(15)^{\mathrm{f}}$ \\
Opossum & $1,188(295)^{\mathrm{g}}$ & $22(0)^{\mathrm{b}}$ & $98(30)^{\mathrm{d}, \mathrm{i}}$ & $86(79)^{\mathrm{d}, \mathrm{e}}$ & $3^{\mathrm{f}}$ & $26(5)^{\mathrm{f}}$ \\
Platypus & $262(315)^{\mathrm{g}, \mathrm{i}}$ & $4(1)^{\mathrm{b}}$ & $270(579)^{\mathrm{b}}$ & $15(112)^{\mathrm{b}}$ & $\mathrm{ND}$ & $\mathrm{ND}$ \\
Chicken & $82(476)^{\mathrm{j}, \mathrm{k}}$ & $3(0)^{\mathrm{b}}$ & $0(0)^{\mathrm{d}}$ & $0(0)^{\mathrm{d}}$ & $2^{\mathrm{f}}$ & $3(0)^{\mathrm{f}}$ \\
Frog & $410(478)^{\mathrm{j}, \mathrm{k}}$ & $2(1)^{\mathrm{b}}$ & $21(2)^{\mathrm{d}}$ & $249(448)^{\mathrm{d}}$ & $0^{\mathrm{f}}$ & $49(12)^{\mathrm{f}}$ \\
Fugu fish & $44(13)^{\mathrm{l}}$ & $13(6)^{\mathrm{m}}$ & $5(0)^{\mathrm{n}}$ & $18(29)^{\mathrm{d}}$ & $4(1)^{\mathrm{f}}$ & $4(0)^{\mathrm{f}}$ \\
Pufferfish & $44(54)^{\mathrm{j}, \mathrm{k}}$ & $\mathrm{ND}$ & $5(0)^{\mathrm{n}}$ & $4(21)^{\mathrm{d}}$ & $5(1)^{\mathrm{f}}$ & $6(0)^{\mathrm{f}}$ \\
Zebrafish & $102(35)^{\mathrm{j}, \mathrm{k}}$ & $109(10)^{\mathrm{m}}$ & $6(0)^{\mathrm{n}}$ & $44(8)^{\mathrm{d}}$ & $1^{\mathrm{f}}$ & $4(0)^{\mathrm{f}}$ \\
\hline
\end{tabular}

The number of nonintact genes, containing truncated genes and pseudogenes, is shown in parentheses.

OR odorant receptor, TAAR trace amine-associated receptor, $N D$ not determined

${ }^{a}$ From Niimura and Nei (2003)

${ }^{b}$ From Grus et al. (2007)

'From Young et al. (2005)

${ }^{\mathrm{d}}$ From Shi and Zhang (2007)

${ }^{\mathrm{e} F r o m ~ Y o u n g ~ a n d ~ T r a s k ~(2007) ~}$

${ }^{f} F r o m$ Shi and Zhang (2006)

hFrom Zhang et al. (2007)

iFrom Grus et al. (2005)

${ }^{\mathrm{j}}$ From Niimura and Nei (2005)

${ }^{k}$ From Niimura and Nei (2006)

'From Alioto and Ngai (2005)

${ }^{\mathrm{m}}$ From Hashiguchi and Nishida (2007)

"From Saraiva and Korsching (2007) 
nine ancestral OR genes (or gene lineages) in the most recent common ancestor (MRCA) of fishes and tetrapods (Niimura and Nei 2005) (Fig. 1b). Eight of the nine ancestral gene lineages have been maintained in fishes (Fig. 1b), probably because the extant teleosts share a similar environment with the MRCA of fishes and tetrapods. By contrast, only two ancestral gene lineages have been retained in mammals or birds, but these gene lineages have expanded extensively in mammals and birds, giving rise to the largest gene family in the mammalian genome. By contrast, these two gene lineages, although present in today's fishes, have not expanded in evolution (Fig. 1b). On the other hand, four gene lineages that are present in fishes have been lost completely in mammals and birds (Fig. 1a,b). Taken together, these observations show that the long-term evolutionary dynamics of OR genes follows the "birth-and-death" process, characterized by frequent gene duplication and gene loss (Nei et al. 1997). The large amount of turnover of OR genes in vertebrate evolution probably reflects the functional requirement for different olfactory abilities in different evolutionary lineages. This view is further supported by the fact that frogs have both mammal-like and fishlike OR genes (Niimura and Nei 2005).

Many OR gene gains and losses have also been observed within mammals. Comparative genomic and phylogenetic analyses show that gene family expansions occurred independently in monotremes, marsupials, and placental mammals. Consequently, many lineage-specific genes are observed in today's mammalian genomes (Fig. 1c). The largest gene family expansion occurred in the marsupial lineage, with at least 750 gene gains. Similarly, more than 400 genes were gained in the cetartiodactyl and rodent lineages (Fig. 1c). On the other hand, the number of gene losses in the primate lineage is much greater than that in other lineages (Niimura and Nei 2007). As shown in Fig. 1c, since the human-mouse split, 385 ancestral genes have been inactivated in the human lineage, while only 55 new OR genes have been acquired. In the mouse lineage, the two numbers are 277 and 623 , respectively. These gene gains and losses explain the dramatic difference in OR gene family size between human and mouse. Furthermore, even when the gene number is similar between two species, the gene content may differ, owing to rapid gene gains and losses (Niimura and Nei 2007).

OR gene number variation also exists among closely related species. Rouquier et al. (2000) found a higher fraction of OR pseudogenes in ten primates than in mice. A subsequent study by Gilad et al. (2004), based on an analysis of 100 orthologous OR genes in 19 nonhuman primate species, found that the percentage of OR pseudogenes is significantly higher in humans, apes, and Old World monkeys than in most New World monkeys and mice (Gilad et al. 2004). Interestingly, in the howler monkey, the only New World monkey with a full trichromatic vision as humans, apes, and Old World monkeys have, approximately $30 \%$ of the genes are pseudogenes, similar to the number in Old World monkeys. On the basis of this result, the authors suggested that the loss of OR genes in humans, apes, and Old World monkeys is a result of the acquisition of trichromatic vision. On the basis of the analysis of 50 orthologous OR genes, Gilad et al. (2003) suggested that humans also have fewer functional genes and more pseudogenes than chimpanzees, which was later substantiated by a genome-wide comparison of human and chimpanzee 


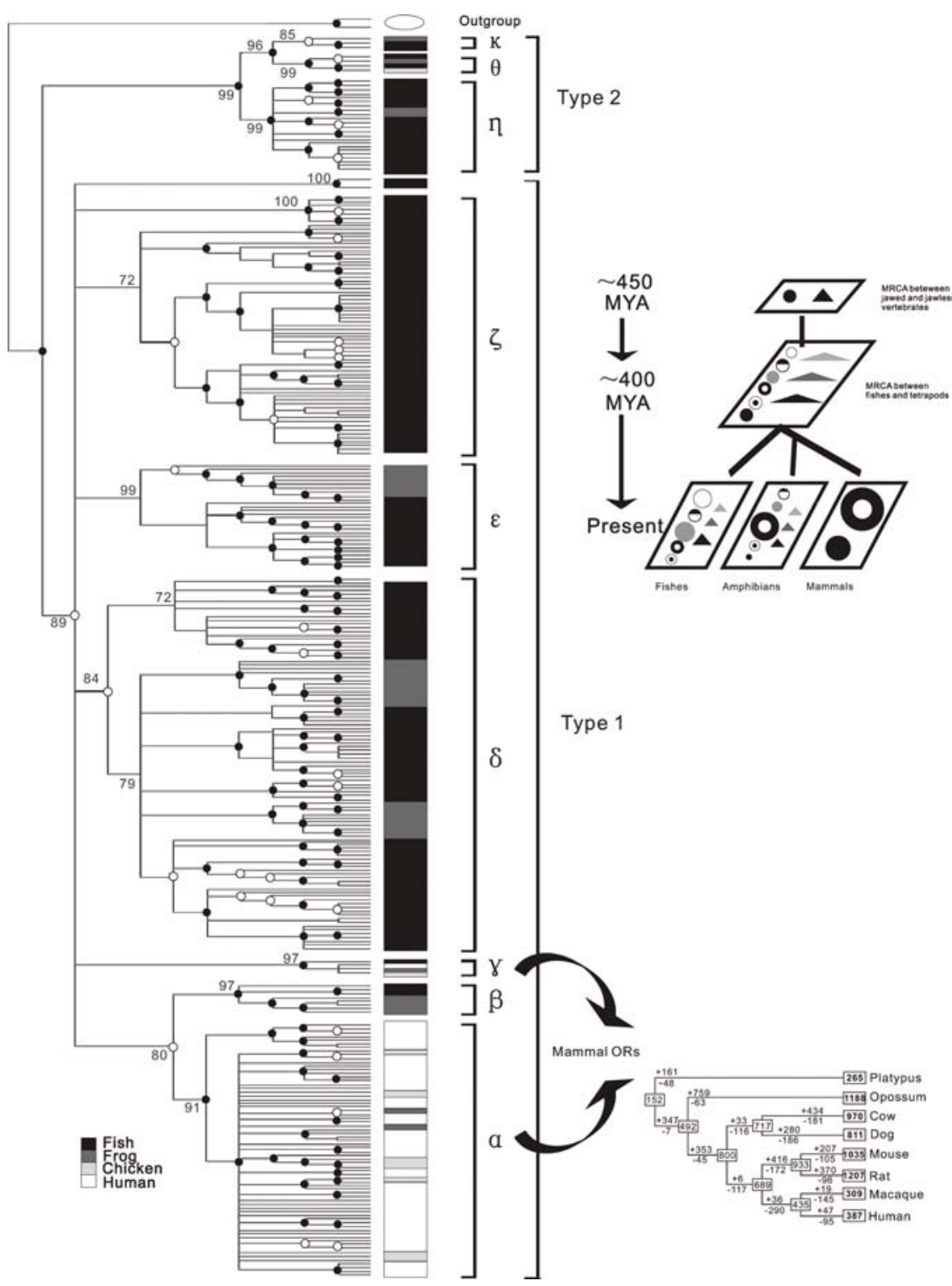

Fig. 1 Evolution of vertebrate odorant receptors $(O R s)$. a Condensed phylogenetic tree for 310 functional OR genes from fishes, frogs, chickens, and humans at the $70 \%$ bootstrap level. The nine major clades are labeled $\alpha, \beta, \gamma, \delta, \varepsilon, \zeta, \eta, \theta$, and $\kappa$. Human class I genes are within the $\alpha$ clade and human class II genes are within the $\gamma$ clade. Open circles and closed circles at nodes represent branches with bootstrap values greater than $90 \%$ and greater than $80 \%$, respectively. b Evolutionary dynamics of vertebrate OR genes. There are at least nine ancestral genes in the most recent common ancestor (MRCA) of fishes and tetrapods. Fishes maintain eight of nine ancestral genes, whereas mammals contain only two of them. $\mathrm{c}$ OR gene gains and losses in mammals. The numbers with plus and minus signs for each branch indicate the numbers of gene gains and losses, respectively, and the numbers in rectangular boxes denote the functional OR genes for the extant or ancestral species. MYA million years ago. (a, c Modified from Niimura and Nei 2003. b Modified from Niimura and Nei 2007) 
OR repertoires (Gilad et al. 2005). More recently, the variation of OR gene number was also identified among different human individuals, which is known as the copy number variation (Trask et al. 1998; Wong et al. 2007). Interestingly, the level of interspecific divergence relative to that of intraspecific variation in OR gene copy number is not significantly different between functional genes and pseudogenes, suggesting that human intraspecific and human-chimpanzee interspecific OR gene number variations may not have any fitness consequence (Nozawa et al. 2007; Zhang 2007).

In addition to the vast variation in gene family size among vertebrates, the remarkable diversity of ORs is also reflected in the high sequence (and potentially functional) variation among alleles found within species. For example, in humans, pygmy populations tend to have higher frequencies of intact alleles than Caucasians in 32 OR genes examined (Gilad and Lancet 2003). A further study of 51 human OR loci in 189 ethnically diverse individuals reached the same conclusion and suggested that different evolutionary forces may have shaped the OR repertoire in different human populations (Menashe et al. 2003). Similarly, great allelic diversity was found in different mouse strains and dog breeds, respectively (Zhang et al. 2004; Tacher et al. 2005). In mice, single nucleotide polymorphisms (SNPs) were counted by comparing two mouse genome sequences, which were derived from different strains (Zhang et al. 2004). It was estimated that there are 2.68 SNPs per OR gene coding region, about twice that in other mouse GPCR genes (Zhang et al. 2004). In dogs, a high level of allelic variation among 20 different breeds was observed in a survey of 16 OR genes among 95 individuals. All genes were found to have SNPs and 50\% of SNPs are nonsynonymous. More interestingly, some SNPs are breed-specific and they may be the basis of breed-specific olfactory sensitivity (Tacher et al. 2005).

\subsection{The TAAR Gene Family - the Second Class of Olfactory Receptor Gene Family}

TAAR genes were initially identified to respond to trace amines in rodents and were later shown to be chemosensory receptors in the MOE (Borowsky et al. 2001; Liberles and Buck 2006). Gloriam et al. (2005) performed the first genome-wide investigation in zebrafish and identified 57 intact TAAR genes, which is almost 10 times the number in human. More recently, a comprehensive scan of ten vertebrate genomes found a large variation in the size of this gene family among vertebrates (Hashiguchi and Nishida 2007). In sharp contrast to the OR gene family, which is larger in tetrapods than in fishes, the TAAR gene family is smaller in tetrapods than in some fishes such as zebrafish and stickleback (Table 1). The largest TAAR gene repertoire, found in zebrafish, has 102 intact genes, whereas the smallest repertoire, in chicken, has only three intact genes (Hashiguchi and Nishida 2007). The comparative genomic and phylogenetic analyses suggested that the large gene repertoires in some fishes are attributable to the genome duplication in teleosts followed by additional gene duplications (Hashiguchi and Nishida 
2007). By contrast, in frog, chicken, and the majority of mammals, the TAAR family lost several ancestral genes but gained virtually no new members. Opossum, cow, mouse, and rat are exceptions, with some gene duplications (Fig. 2). These findings suggest that the TAAR gene family is also subject to the birth-and-death evolutionary process observed in the OR gene family and that biogenic amine odorants are more important for fish than for tetrapods (Hashiguchi and Nishida 2007).

\section{Vomeronasal Receptor Gene Families}

The vomeronasal system is present in most tetrapods (amphibians, reptiles, and mammals), but is absent in fishes (Dulac and Torello 2003). Thus, the nomenclature of the fish chemosensory receptors that are homologous to mammalian vomeronasal receptors has been confusing. On the basis of sequence homology, some authors termed them "V1R-like" and "V2R-like" genes (Hashiguchi and Nishida 2005, 2006; Pfister and Rodriguez 2005; Pfister et al. 2007), while some authors separately designated them as "olfactory receptor A family GPCR" and "olfactory receptor C family GPCR" by considering their expression pattern and phylogenetic position in the GPCR family (Alioto and Ngai 2006; Saraiva and Korsching 2007). Here we use the former terminology for three reasons. First, most, if not all, VR-like genes have been identified by sequence homology and their expression pattern and biological function are usually unknown. Second, although teleost fishes do not have a morphologically distinct vomeronasal organ, they may have a primordial vomeronasal system (Grus and Zhang 2006). Third, the latter nomenclature is also confusing and undistinguishable from that for other chemosensory receptors expressed in the MOE.

\subsection{The V1R Gene Family - the Family with the Highest Among-Species Variation in Gene Family Size}

In 1995, V1R genes were first identified in rats by comparative hybridization of complementary DNA libraries from individual VSNs (Dulac and Axel 1995). The first complete V1R repertoire was described for mouse by Rodriguez et al. (2002). In this work, they identified 137 functional V1R genes from the mouse draft genome sequence and subsequently classified them into 12 subfamilies according to protein sequence identity (Rodriguez et al. 2002). In human, the entire V1R repertoire, including functional genes and pseudogenes, has approximately 200 members. However, the functional V1R repertoire is small, with only four open reading frames in most individuals (Rodriguez and Mombaerts 2002; Zhang and Webb 2003). Grus et al. (2005) identified functional V1R genes from five orders of placental and marsupial mammals (Table 1). The intact V1R repertoire size varies by at least 23-fold among mammals with functional VNOs and this size ratio represents the greatest among-species variation in gene family size of all 


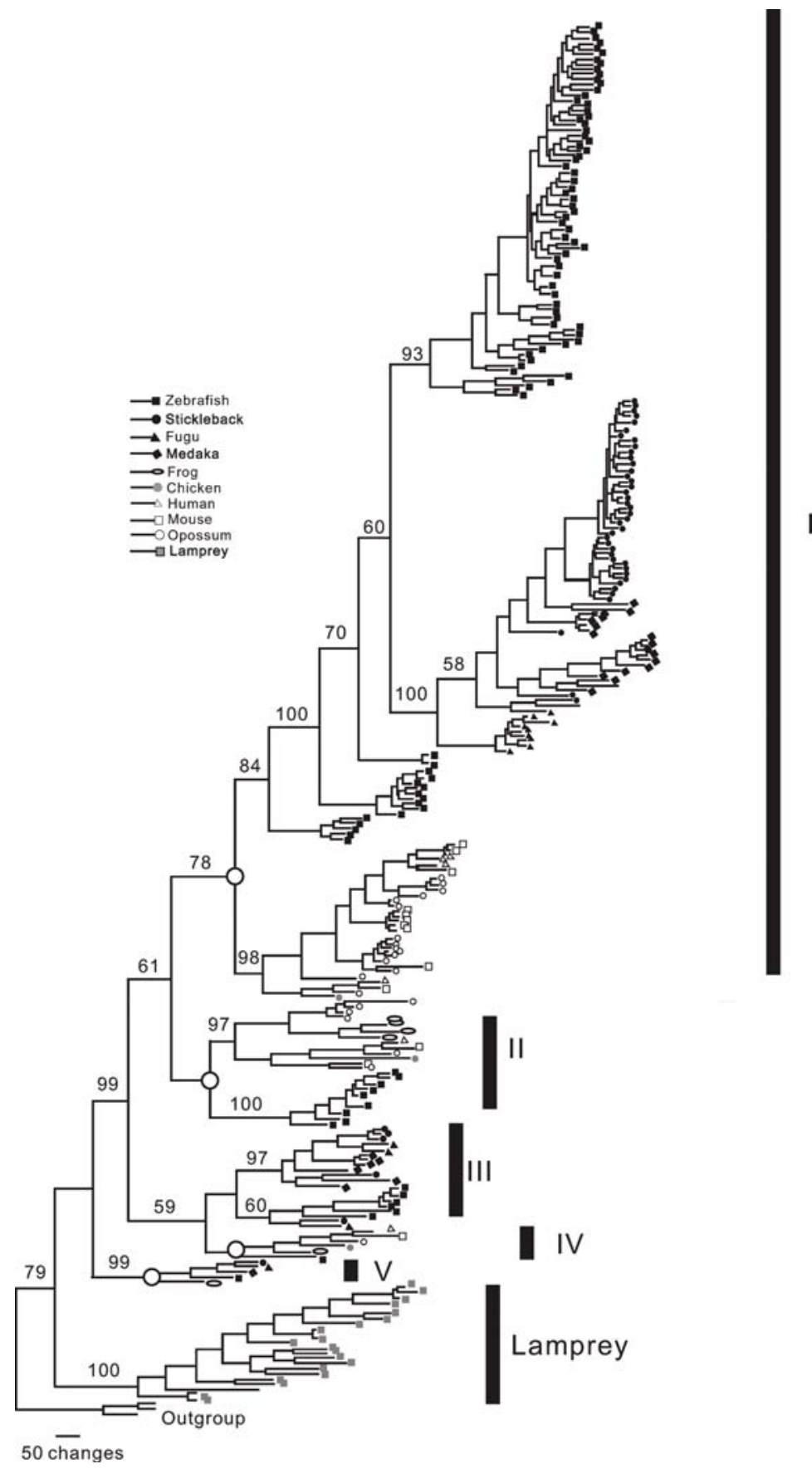

Fig. 2 Phylogenetic tree of 268 trace amine-associated receptor genes identified from ten vertebrates. The tree was reconstructed by the maximum-likelihood method using nucleotide sequences. Bootstrap percentages greater than 50 are shown on interior branches. White dots on nodes indicate the MRCA of fishes and tetrapods. (Modified from Hashiguchi and Nishida 2007) 
mammalian gene families (Grus et al. 2005). Young et al. (2005) made similar findings. A more recent study found that the platypus, a semiaquatic monotreme, has the largest V1R repertoire characterized to date, with 270 potentially functional genes and 579 pseudogenes. Thus, the functional V1R repertoire size varies by at least 34-fold among mammals with functional VNOs (Grus et al. 2007). This large variation in V1R repertoire size is also observed between closely related species. For example, mouse has 191 functional V1R genes, about 50\% more than the number in rat (117) (Shi et al. 2005; Young et al. 2005; Zhang et al. 2007). The number of V1R genes also varies tremendously among nonmammalian vertebrates (Shi and Zhang 2007). No V1R genes were found in chicken, consistent with the fact that birds have neither VNO nor VNO-mediated olfaction (Keverne 1999). A total of 21 functional genes and two pseudogenes was found in the western clawed frog (Shi and Zhang 2007). In contrast to mammals, fishes have highly conserved V1R-like repertoires, containing four genes in two pufferfish species and five genes in zebrafishes, stickleback, and medaka, respectively (Hashiguchi and Nishida 2006; Saraiva and Korsching 2007; Shi and Zhang 2007). Interestingly, the number of intact V1R genes is positively correlated with the morphological complexity of the VNO, suggesting that VNO morphology is a good indicator of vomeronasal sensitivity (Grus et al. 2005).

A phylogenetic analysis of all vertebrate V1Rs suggests that V1R genes can be divided into at least three major clades that diverged from one another before the separation of tetrapods and teleosts (Shi and Zhang 2007) (Fig. 3a). Clade 1 now contains genes from frog and mammals, but was lost in fishes. Clade 2 and clade 3 include frog and fish genes, which are absent in mammals. Major expansions of the V1R gene repertoire occurred in some mammals (clade 1), whereas minor expansions occurred in frog (clades 1 and 2) (Fig. 3a) (Shi and Zhang 2007). Very recently, two very divergent V1R-like genes were found in teleost fishes (Saraiva and Korsching 2007). It appears that the evolutionary diversity of V1R genes in fishes is much larger than that in tetrapods, although the gene family size is smaller in fishes than in tetrapods.

In mammals, both gene duplicate and pseudogenization have played important roles in generating the remarkable among-species variation in V1R gene repertoire (Grus et al. 2005; Young et al. 2005). On one hand, substantial numbers of gene duplication events occurred independently in monotremes, marsupials, and placentals, giving rise to platypus-specific, opossum-specific, and placental-specific gene clusters (Grus et al. 2005, 2007) (Fig. 3a). Following the initial gene duplications in the MRCA of placental mammals, additional expansions occurred most prominently in rodents, in which the evolution of the V1R repertoire is characterized by rapid gene turnover and species-specific phylogenetic clustering (Grus and Zhang 2004; Lane et al. 2004; Grus et al. 2005; Shi et al. 2005; Young et al. 2005) (Fig. 3a). Extreme examples include two subfamilies of V1R genes that appear in mouse but not in rat (Grus and Zhang 2004; Shi et al. 2005). On the other hand, human, cow, and dog lost many ancestral V1R genes. In humans, only three of the 12 ancestral family groups were observed. This is also the case in cow and dog, where at least four ancestral family groups are missing (Grus et al. 2005; Young et al. 2005). 


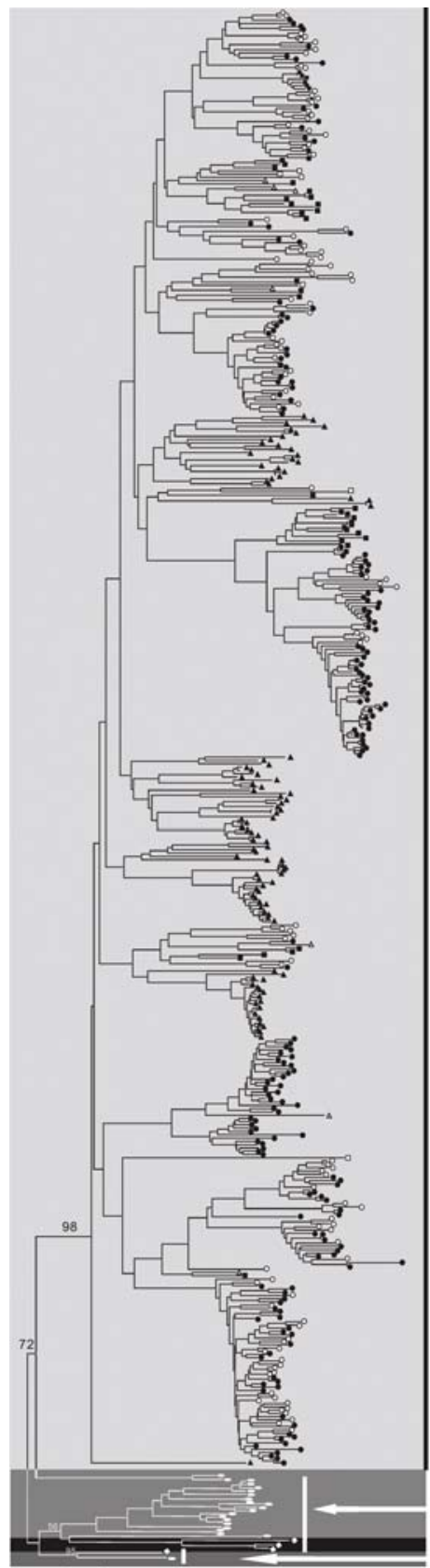

a $\overrightarrow{0.1}$

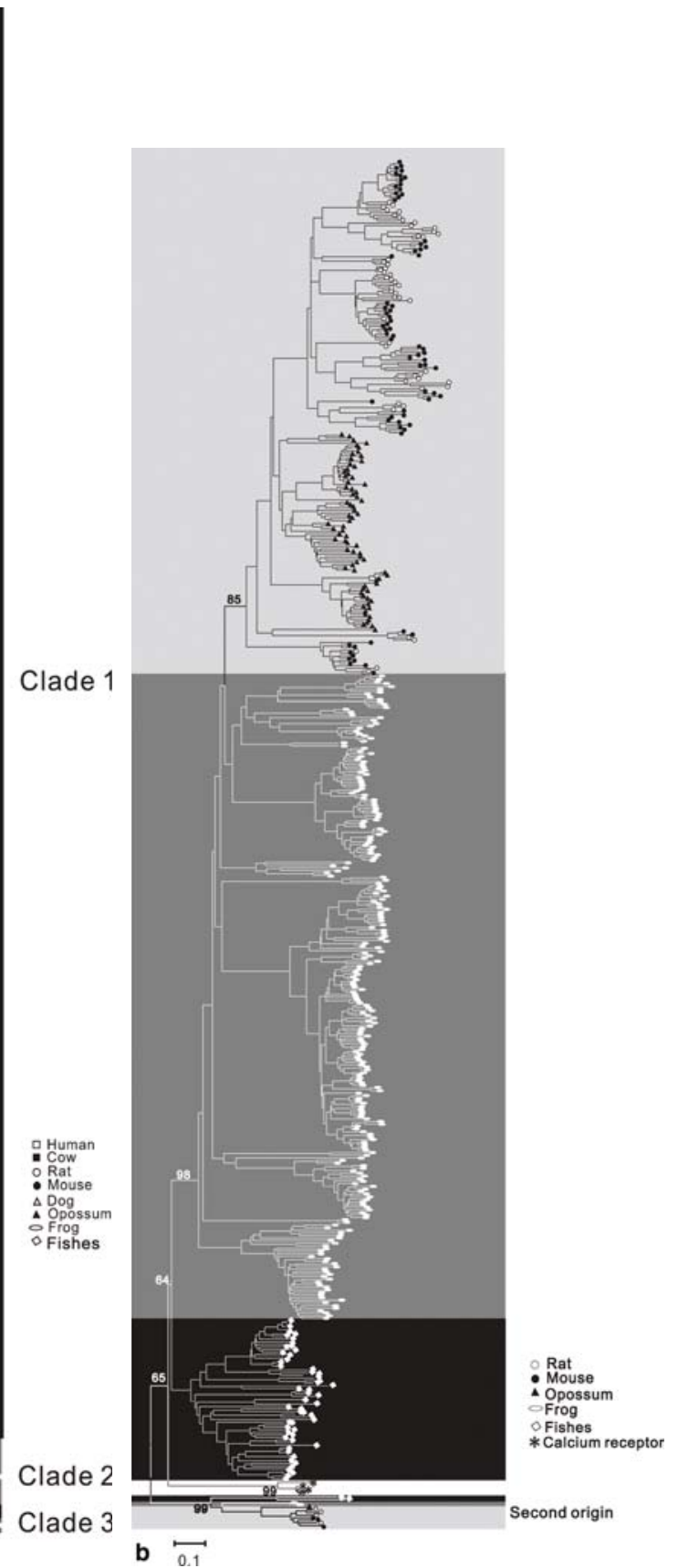

Fig. 3 Neighbor-joining trees of intact vomeronasal receptors from vertebrates. a The V1R tree. b The V2R tree. The trees were reconstructed with protein Poisson distances. Bootstrap percentages for some major groups are presented. Vomeronasal receptors from the mammals, frogs, and fishes are shown by light grey background, dark grey background, and black background, respectively. (Modified from Shi and Zhang 2007) 


\subsection{The V2R Gene Family - Independent Origins of Two Types of $V 2 R s$}

The first extensive characterization of any V2R gene repertoire was conducted in 2005 (Yang et al. 2005), 8 years after the initial identification of the gene family (Dulac 1997; Herrada and Dulac 1997; Ryba and Tirindelli 1997; Yang et al. 2005). Comparative genomic studies showed that the across-vertebrate variation in gene number for V2R genes is not lower than that for V1R genes. The largest V2R repertoire is unexpectedly found in frog, with 249 intact genes and 408 disrupted genes. By contrast, no intact V2R genes are found in chicken, cow, dog, and human. In addition, 4, 18, 44, 90, 120, and 70 intact V2R genes are present in the green spotted pufferfish, fugu, zebrafish, opossum, mouse, and rat, respectively (Shi and Zhang 2007; Young and Trask 2007) (Table 1).

In comparison with the V1R gene repertoire, the V2R repertoire is frequently lost in terrestrial vertebrates. There are at least three independent losses of the entire V2R repertoire in chicken, human, and cow/dog, respectively, which is consistent with the loss of certain morphological features of the VNO (Shi and Zhang 2007). By contrast, the V2R gene repertoire expanded in teleosts with prominent patterns of lineage-specific gene amplifications (Alioto and Ngai 2006; Hashiguchi and Nishida 2006; Shi and Zhang 2007) (Fig. 3b). The V2R repertoire also expanded in rodents and opossums and exhibit the characteristics of rapid gene turnover and speciesspecific gene clustering (Yang et al. 2005; Young and Trask 2007), as seen in V1Rs. Interestingly, the V2R gene family tree has an unique branching pattern, where not all V2R genes cluster in one monogenetic clade. The phylogenetic analysis shows that V2Rs of family C (also termed V2R2 subfamily) are quite different from those of families $\mathrm{A}$ and $\mathrm{B}$ and are evolutionarily closer to $\mathrm{Ca}^{2+}$-sensing receptors than to V2Rs of families A and B. This observation suggests that family $\mathrm{C}$ and families $\mathrm{A}$ and B had independent origins (Yang et al. 2005) (Fig. 3b). This evolutionary history may explain the differences in expression pattern and transport mechanism between the two types of V2Rs and suggests that family C V2Rs may be functionally distinct from those of families A and B (Yang et al. 2005; Young and Trask 2007).

\subsection{Diversity of Protein Families Interacting with Vomeronasal Receptors}

In mice, there are two gene families that are known to function in concert with V2Rs. One of them is the M10 family of major histocompatibility class Ib molecules, which appear to function as escort molecules in the transport of some V2Rs to the cell membrane of vomeronasal sensory neurons (Loconto et al. 2003). The second is the exocrine gland peptide (ESP) family, which can activate the V2R-expressing vomeronasal sensory neurons and have been suggested to be ligands of some V2Rs (Kimoto et al. 2005). A recent study compared these two gene families in 11 verte- 
brates and found them to have been coevolving with V2Rs (Shi and Zhang 2007). Consistent with the absence of V2R genes in dog, cow, and human, neither M10 nor ESP genes are found in these species. Unexpectedly, however, M10 and ESP genes are not found in the opossum genome, despite the presence of numerous intact V2R genes, suggesting that the requirement of M10 molecules for the transport of some V2Rs to cell membranes is probably a rodent-specific phenomenon and the use of ESPs as potentially V2R-recognizing pheromones is also rodent-specific (Shi and Zhang 2007). Interestingly, these two gene families share with the V2R family the rapid birth-and-death evolutionary pattern. Very recently, major urinary proteins were identified as V2R-recognizing pheromones in mice and the major urinary protein family size was found to covary with the V2R family size across vertebrates (Chamero et al. 2007).

A similar story can be told for the transient receptor potential channel C2 (TRPC2) gene, which encodes an ion channel indispensable for vomeronasal signal transduction. TRPC2 is absent in the catarrhine primates (humans, apes, and Old Word monkeys), which possess only vestigial VNOs and have no or significantly reduced ability of pheromone detection (Liman and Innan 2003; Zhang and Webb 2003). Consistently, the majority of V1R genes and all V2R genes have disrupted open reading frames in catarrhine primates (Zhang and Webb 2003; Shi and Zhang 2007; Young and Trask 2007). Similarly, the lack of the TRPC2 gene and V1R and $\mathrm{V} 2 \mathrm{R}$ genes is observed in chicken, reflecting the ancient loss of the VNO in birds. Conversely, the TRPC2 open reading frame is maintained in all vertebrates known to have functional vomeronasal receptors (Grus and Zhang 2006).

\section{Taste Receptor Gene Families}

\subsection{T2R Gene Family - the More Variable Group of Taste Receptors}

Taste receptor genes were the last chemoreceptor genes to be isolated. In 2000, the T2R gene family (also known as TRBs or Tas2Rs) was identified and two mouse T2R genes were shown to be bitter taste receptors (Adler et al. 2000; Chandrashekar et al. 2000; Matsunami et al. 2000). To date, the complete T2R gene repertoires have been described in mammals, birds, amphibians, and some fishes (Conte et al. 2002, 2003; Go 2006; Shi and Zhang 2006). In addition, a small number of T2R genes have also been described in several nonhuman primates (Parry et al. 2004; Wang et al. 2004; Fischer et al. 2005; Go et al. 2005). As shown in Table 1, the T2R gene repertoire varies extremely among vertebrates, ranging from three genes in chicken to 50 genes in amphibians (Go 2006; Shi and Zhang 2006). This observation is consistent with the fact that bitter taste perception, as a mechanism of guarding against the ingestion of toxins, varies enormously among vertebrates that have different diets and environments. Most interestingly, the comparative genomic 
analysis shows that the size of the gene family appears to be positively correlated with the number of bitter toxins that an organism is likely to encounter (Shi and Zhang 2006). Omnivorous mammals tend to have the largest T2R gene repertoires and the lowest fractions of T2R pseudogenes, probably because they consume both animal and plant tissues and consequently encounter more toxic compounds than herbivorous and carnivorous mammals do. By contrast, carnivores have a small number of functional T2R genes than herbivores, because animal tissues contain fewer toxins than plant tissues do (Shi and Zhang 2006). Cow was found to have the highest proportion of T2R pseudogenes (44\%), suggesting that detecting poisons in the diet is not as important in ruminants as in other animals, probably owing to the detoxification role of cow's rumen microbes (Shi and Zhang 2006). These hypotheses need to be scrutinized in more mammalian species.

A phylogenetic analysis of all vertebrate T2R genes suggests that there were multiple T2R genes in the common ancestor of tetropods and teleosts, because T2R genes from teleost fishes do not cluster into one monophyletic clade (Fig. 4a). In addition, the overall evolutionary pattern of vertebrate T2R genes follows the birth-and-death process, similar to that observed in several other chemoreceptor gene families. Specifically, the T2R gene repertoire expanded considerably in the common ancestor of tetrapods, followed by additional independent expansions in frogs and mammals and contraction in chicken (Go 2006; Shi and Zhang 2006). The comparative genomic analysis of human and mouse T2R genes shows that some T2R genes exhibit one-to-one orthologous pairing, whereas others form species (lineage) specific clusters, in which the genes from the same species cluster together in the phylogenetic tree. These species-specific genes are the results of tandem gene duplications and are probably used for detecting speciesspecific bitter tastants (Shi et al. 2003). One-to-one orthologous genes were found to be subject to stronger selective constraints than species-specific genes, suggesting that each of the one-to-one orthologous genes is possibly detecting one or several distinct bitter compounds that are encountered by a wide range of animals (Shi et al. 2003). This still requires further verification by functional analysis of the receptors, although two recent evolutionary studies (Go 2006; Shi and Zhang 2006) that extended the study of T2Rs to nine additional vertebrate species supported the hypothesis.

Comparative analysis of the T2R gene family between several species of primates and rodents revealed that the genes were under reduced selective constraints in primates compared with rodents (Parry et al. 2004; Wang et al. 2004; Fischer et al. 2005; Go et al. 2005). The proportion of pseudogenes in the T2R repertoire is lower in mice (15\%) than in apes $(21-28 \%)$, which is in turn lower than that in humans (31\%) (Fischer et al. 2005; Go et al. 2005). The prevalence of lineage- or species-specific pseudogenes in primates further supports this conclusion (Go et al. 2005). In addition, the ratio of nonsynonymous to synonymous substitution rates for T2R genes is lower in rodents than in primates (Wang et al. 2004; Fischer et al. 2005; Go et al. 2005). The most likely explanation is that primates have reduced bitter taste needs owing to changes in the environment and diet (Go et al. 2005). Actually, some ecological studies support this explanation. For instance, meat 
accounts for $2-13 \%$ of diet in chimpanzees, whereas it has never been found in the diet of other apes (Wang et al. 2004). Furthermore, there were significant changes in human diet, such as decreased intake of plant tissues and the controlled use of fire to detoxify food (Wang et al. 2004). Both factors may have caused a reduction in the importance of bitter taste and consequently triggered a functional relaxation on T2Rs in humans, as has been observed (Wang et al. 2004).

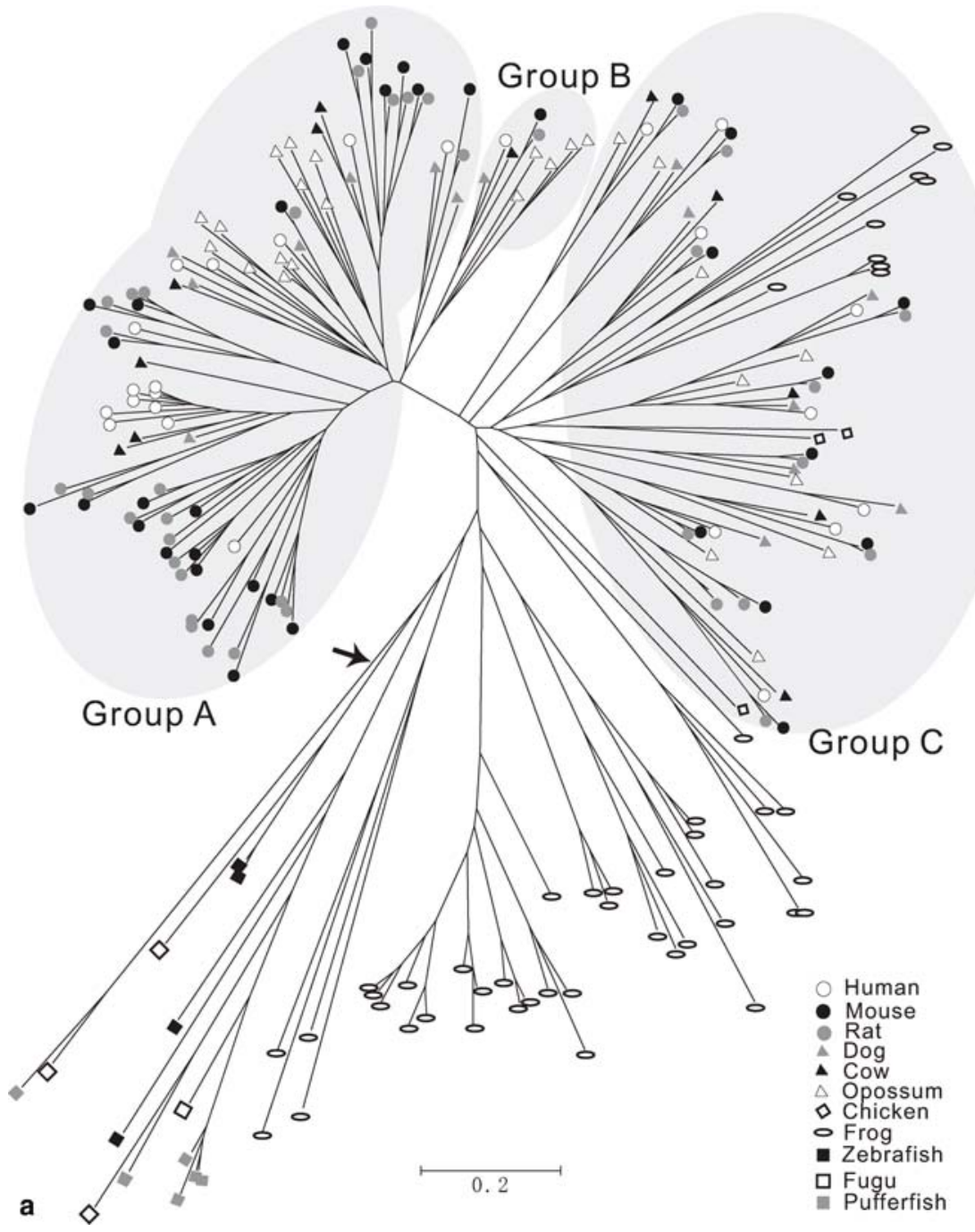

(continued) 


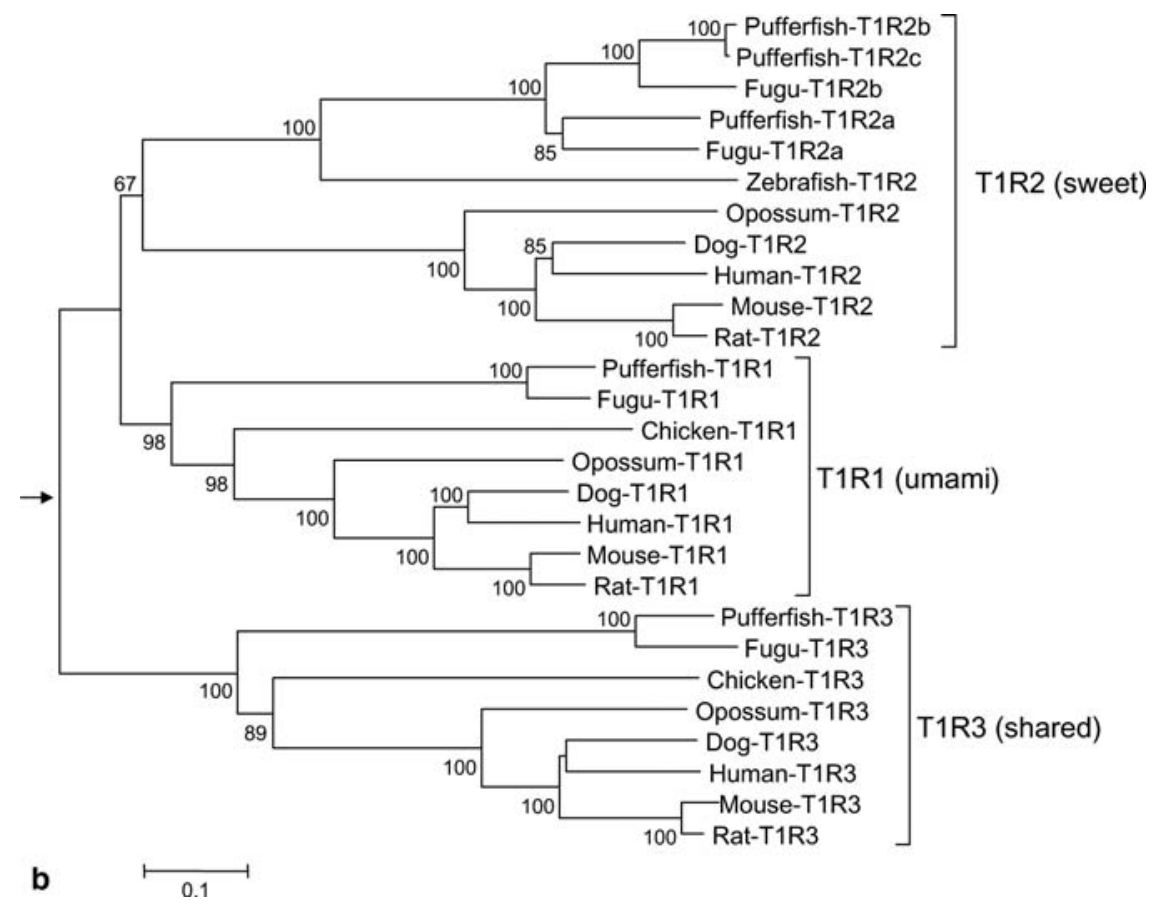

Fig. 4 Phylogenetic relationships of vertebrate intact T1R and T2R genes. a The T1R tree. b The $\mathrm{T} 2 \mathrm{R}$ tree. The tree was reconstructed by the neighbor-joining method with protein Poisson distances. Bootstrap percentages greater than 50 are shown on interior branches. Groups A, B, and C in the T2R tree were previously defined on the basis of the tree of human and mouse T2R genes (Shi et al. 2003). The arrow indicates the root of the tree, which was determined by using vertebrate V1R genes as outgroups for T2R genes, and using V2R genes as outgroups in the T1R tree. (Reprinted from Shi and Zhang 2006, copyright 2006, with permission from Oxford University Press)

\subsection{The T1R Gene Family - the More Conserved Group of Taste Receptors}

In 1999, two GPCR genes that are now named T1R1 and T1R2 were described in subsets of taste receptor cells (Hoon et al. 1999). The third T1R gene, T1R3, was identified almost simultaneously by six groups in 2001 (Kitagawa et al. 2001; Max et al. 2001; Montmayeur et al. 2001; Nelson et al. 2001; Sainz et al. 2001; Zhao et al. 2003). In contrast to the T2R gene family, the T1R family is evolutionary conserved in both gene family size and gene sequence (Shi and Zhang 2006). In terms of the family size, the number of T1R genes is virtually constant across mammals, which might reflect the necessity of both sweet and umami tastes among mammals (Shi and Zhang 2006). But the number of T1R genes varies in some nonmammalian vertebrates, including gene duplications observed in pufferfish and stickleback and gene losses found in western clawed frog and chicken (Shi and Zhang 2006; Hashiguchi et al. 2007). Interestingly, 
the western clawed frog does not have any T1R genes, although it has many T2R genes. In chicken, the T1R2 gene is missing (Shi and Zhang 2006) (Fig. 4b). In addition, cats and closely related carnivores are also known to miss the T1R2 genes, which is likely the cause of the insensitivity to sweet tastants in these species ( $\mathrm{Li}$ et al. 2005). Thus, pseudogenization of T1R2 happened multiple times in evolution.

At the protein sequence level, T1R genes evolve more slowly than T2R genes at both interspecific and intraspecific levels. For interspecific comparison, sequence divergence among orthologs is significantly lower for T1R genes than for T2R genes when human, mouse, rat, and opossum genes were compared (Shi and Zhang 2006). Within human populations, the mean pairwise difference per nucleotide between sequences of T1Rs is also lower than that for T2Rs (Kim et al. 2005, 2006).

In sum, the contrasting evolutionary modes between T1R and T2R gene families suggest the relative constancy in the number and type of sweet and umami tastants encountered by various vertebrates or low binding specificities of T1Rs but a large variation in the number and type of bitter compounds detected by different species.

\section{Adaptive Diversification of Chemoreceptor Gene Repertoires}

Why do the chemosensory receptor gene families vary so much among vertebrates? One potential answer is the variable functional requirements for different species to adapt to their specific environments. Here we summarize evidence for the adaptive hypothesis at three levels: (1) gene family, (2) newly duplicated paralogous genes, and (3) intraspecific variation.

Adaptive evolution at the gene family level may be detected by comparing the gene repertoires of nasal chemosensory receptors in terrestrial vertebrates with those in aquatic vertebrates because terrestrial vertebrates tend to encounter volatile chemicals, while aquatic vertebrates encounter water-soluble chemicals. A recent analysis of V1R, V2R, and OR gene families in several vertebrate genomes showed that the ratio of the number of intact V1R genes to that of intact V2R genes increased by approximately 50 fold in the evolutionary transition from water to land. Note that circumstantial evidence suggests that $\mathrm{V} 1 \mathrm{Rs}$ tend to recognize airborne molecules, while V2Rs tend to recognize water-soluble ligands. The comparison of the number of class II ORs to that of class I ORs, which have been suggested to bind to volatile and water-solvable molecules, respectively, also shows a similar pattern of change during the evolutionary transition of vertebrates from aquatic to terrestrial environments. By contrast, a comparison of pairs of randomly chosen gene families from the zebrafish and mouse genomes does not show such dramatic changes, indicating that the observation made in the nasal chemoreceptor genes is unlikely caused by random gene turnovers (Shi and Zhang 2007). Rather, the two nasal chemo- 
sensory systems appear to show a consistent pattern of a shift from receptors for water-soluble molecules to those for volatiles in the vertebrate transition from water to land, reflecting a rare case of adaptation to terrestrial life at the gene family level.

Gene duplication is believed to be the primary source of new genes with novel functions (Zhang 2003). In chemoreceptor gene families, gene duplication occurs frequently and the newly generated genes may acquire the ability to recognize new ligands, which could increase an organism's fitness. As expected, analysis of ORs, V1Rs, V2Rs, T1Rs, and T2Rs revealed positive selection acting on newly duplicated genes in most vertebrate lineages (Hughes and Hughes 1993; Mundy and Cook 2003; Shi et al. 2003, 2005; Emes et al. 2004; Alioto and Ngai 2005, 2006; Yang et al. 2005; Shi and Zhang 2006). More interestingly, positive selection tends to happen in potential ligand-binding regions. For instance, the analysis of eight closely related human T2R genes suggested positive selection in extracellular domains, while purifying selection in transmembrane and intracellular domains (Shi et al. 2003). Although no crystal structure of T2Rs has been solved, existing functional data suggest that extracellular domains of T2Rs are involved in binding to ligands (Soranzo et al. 2005). Positive selection was also detected in extracellular domains in V1Rs, which are most closely related to T2Rs in sequence (Mundy and Cook 2003; Shi et al. 2005). These results contrast the majority of positively selected sites in ORs, which are located in transmembrane domains that are thought to be the binding pocket in ORs (Emes et al. 2004). For the V2R and T1R gene families, most positively selected sites are mapped to the long N-terminus, which is believed to be involved in heterodimerization or homodimerization and ligand binding (Yang et al. 2005; Shi and Zhang 2006). Together, these positive selection analyses suggest that newly generated chemoreceptor genes tend to be subject to diversifying selection, probably because of the ability to recognize a diverse array of chemicals that the animals encounter in exploring new habitats and foods.

As described above, sequence variation of chemoreceptor genes is prevalent even within species. If these polymorphisms affect an individual's fitness such as mate selection and sibling sustenance, some of them may be under positive selection. There is now evidence supporting this possibility. For example, Zhang et al. (2004) compared V1R gene sequences from two mouse draft sequences which were derived from different inbred mouse strains. They found a high ratio of nonsynonymous to synonymous substitutions, a possible result of positive selection on these genes. In humans, most chemoreceptor genes are under relaxed selective constraints. However, positive selection has been detected in the human T2R16 gene, which encodes a $\beta$-glucopyranoside receptor (Bufe et al. 2002). By analyzing the sequences from different human populations, Soranzo et al. (2005) detected signatures of positive selection on a derived allele, which was found in all human populations except Africans. Compared with the ancestral allele, the derived allele exhibits increased sensitivity in detecting -glucopyranoside. It was suggested that the derived allele may provide better protection against harmful cyanogenic plant foods and natural toxins (Soranzo 
et al. 2005). Another interesting case is the T2R38 gene, which is largely responsible for the human polymorphism in tasting phenylthiocarbamide (Kim et al. 2003). Balancing selection was suggested to maintain both taster and nontaster T2R38 alleles in human populations (Wooding et al. 2004), although a subsequent analysis found the evidence for balancing selection unconvincing (Wang et al. 2004). Interestingly, chimpanzees are also known to have tasters and nontasters of phenylthiocarbamide, but the nontaster allele is apparently a null allele (Wooding et al. 2006).

\section{Conclusions}

The hallmark of vertebrate chemoreceptor gene family evolution is the extremely high diversity of gene family size and gene sequence among species. The general genetic mechanisms involved in generating this pattern include frequent gene duplication and pseudogenization, conforming to the "birth-and-death" process (Nei et al. 1997). Adaptation to changing environments and diets is likely the major selective force behind this evolutionary process, in addition to the random factor of genomic drift (Nei 2007). Although evolutionary and genomic studies have resulted in enormous advances in this field in the last several years, many fundamental questions are yet to be answered (Mombaerts 2004; Meyerhof 2005). It is expected that evolutionary analysis, coupled with functional assays of chemoreceptors, will yield useful information on the molecular mechanisms and selective forces behind vertebrate chemoreceptor gene diversification.

Acknowledgement This work was supported by a start-up fund of "Hundreds-Talent Program" from Chinese Academy of Sciences to P.S. and research grants from the National Institutes of Health to J.Z.

\section{References}

Adler E, Hoon MA, Mueller KL, Chandrashekar J, Ryba NJ, Zuker CS (2000) A novel family of mammalian taste receptors. Cell 100:693-702

Alioto TS, Ngai J (2005) The odorant receptor repertoire of teleost fish. BMC Genomics 6:173

Alioto TS, Ngai J (2006) The repertoire of olfactory C family G protein-coupled receptors in zebrafish: candidate chemosensory receptors for amino acids. BMC Genomics 7:309

Behrens M, Foerster S, Staehler F, Raguse JD, Meyerhof W (2007) Gustatory expression pattern of the human TAS2R bitter receptor gene family reveals a heterogenous population of bitter responsive taste receptor cells. J Neurosci 27:12630-12640

Borowsky B, Adham N, Jones KA, Raddatz R, Artymyshyn R, Ogozalek KL, Durkin MM, Lakhlani PP, Bonini JA, Pathirana S, Boyle N, Pu X, Kouranova E, Lichtblau H, Ochoa FY, Branchek TA, Gerald C (2001) Trace amines: identification of a family of mammalian G protein-coupled receptors. Proc Natl Acad Sci USA 98:8966-8971 
Buck LB (2000) The molecular architecture of odor and pheromone sensing in mammals. Cell 100:611-618

Buck L, Axel R (1991) A novel multigene family may encode odorant receptors: a molecular basis for odor recognition. Cell 65:175-187

Bufe B, Hofmann T, Krautwurst D, Raguse JD, Meyerhof W (2002) The human TAS2R16 receptor mediates bitter taste in response to beta-glucopyranosides. Nat Genet 32:397-401

Chamero P, Marton TF, Logan DW, Flanagan K, Cruz JR, Saghatelian A, Cravatt BF, Stowers L (2007) Identification of protein pheromones that promote aggressive behaviour. Nature 450:899-902

Chandrashekar J, Mueller KL, Hoon MA, Adler E, Feng L, Guo W, Zuker CS, Ryba NJ (2000) T2Rs function as bitter taste receptors. Cell 100:703-711

Conte C, Ebeling M, Marcuz A, Nef P, Andres-Barquin PJ (2002) Identification and characterization of human taste receptor genes belonging to the TAS2R family. Cytogenet Genome Res 98:45-53

Conte C, Ebeling M, Marcuz A, Nef P, Andres-Barquin PJ (2003) Evolutionary relationships of the Tas2r receptor gene families in mouse and human. Physiol Genomics 14:73-82

Dulac C (1997) Molecular biology of pheromone perception in mammals. Semin Cell Dev Biol 8:197-205

Dulac C, Axel R (1995) A novel family of genes encoding putative pheromone receptors in mammals. Cell 83:195-206

Dulac C, Torello AT (2003) Molecular detection of pheromone signals in mammals: from genes to behaviour. Nat Rev Neurosci 4:551-562

Emes RD, Beatson SA, Ponting CP, Goodstadt L (2004) Evolution and comparative genomics of odorant- and pheromone-associated genes in rodents. Genome Res 14:591-602

Fischer A, Gilad Y, Man O, Paabo S (2005) Evolution of bitter taste receptors in humans and apes. Mol Biol Evol 22:432-436

Gilad Y, Lancet D (2003) Population differences in the human functional olfactory repertoire. Mol Biol Evol 20:307-314

Gilad Y, Wiebe V, Przeworski M, Lancet D, Paabo S (2004) Loss of olfactory receptor genes coincides with the acquisition of full trichromatic vision in primates. PLoS Biol 2:E5

Gilad Y, Man O, Glusman G (2005) A comparison of the human and chimpanzee olfactory receptor gene repertoires. Genome Res 15:224-230

Gilad Y, Man O, Paabo S, Lancet D (2003) Human specific loss of olfactory receptor genes. Proc Natl Acad Sci U S A 100:3324-3327

Gloriam DE, Bjarnadottir TK, Yan YL, Postlethwait JH, Schioth HB, Fredriksson R (2005) The repertoire of trace amine G-protein-coupled receptors: large expansion in zebrafish. Mol Phylogenet Evol 35:470-482

Glusman G, Yanai I, Rubin I, Lancet D (2001) The complete human olfactory subgenome. Genome Res 11:685-702

Go Y (2006) Proceedings of the SMBE Tri-National Young Investigators' Workshop 2005. Lineage-specific expansions and contractions of the bitter taste receptor gene repertoire in vertebrates. Mol Biol Evol 23:964-972

Go Y, Satta Y, Takenaka O, Takahata N (2005) Lineage-specific loss of function of bitter taste receptor genes in humans and nonhuman primates. Genetics 170:313-326

Grus WE, Zhang J (2004) Rapid turnover and species-specificity of vomeronasal pheromone receptor genes in mice and rats. Gene 340:303-312

Grus WE, Zhang J (2006) Origin and evolution of the vertebrate vomeronasal system viewed through system-specific genes. Bioessays 28:709-718

Grus WE, Shi P, Zhang YP, Zhang JZ (2005) Dramatic variation of the vomeronasal pheromone receptor gene repertoire among five orders of placental and marsupial mammals. Proc Natl Acad Sci USA 102:5767-5772

Grus WE, Shi P, Zhang JZ (2007) Largest vertebrate vomeronasal type 1 receptor gene repertoire in the semiaquatic platypus. Mol Biol Evol 24:2153-2157 
Hashiguchi Y, Nishida M (2005) Evolution of vomeronasal-type odorant receptor genes in the zebrafish genome. Gene 362:19-28

Hashiguchi Y, Nishida M (2006) Evolution and origin of vomeronasal-type odorant receptor gene repertoire in fishes. BMC Evol Biol 6:76

Hashiguchi Y, Nishida M (2007) Evolution of trace amine associated receptor (TAAR) gene family in vertebrates: lineage-specific expansions and degradations of a second class of vertebrate chemosensory receptors expressed in the olfactory epithelium. Mol Biol Evol 24:2099-2107

Hashiguchi Y, Furuta Y, Kawahara R, Nishida M (2007) Diversification and adaptive evolution of putative sweet taste receptors in threespine stickleback. Gene 396:170-179

Herness MS, Gilbertson TA (1999) Cellular mechanisms of taste transduction. Annu Rev Physiol 61:873-900

Herrada G, Dulac C (1997) A novel family of putative pheromone receptors in mammals with a topographically organized and sexually dimorphic distribution. Cell 90:763-773

Hoon MA, Adler E, Lindemeier J, Battey JF, Ryba NJ, Zuker CS (1999) Putative mammalian taste receptors: a class of taste-specific GPCRs with distinct topographic selectivity. Cell 96:541-551

Hughes AL, Hughes MK (1993) Adaptive evolution in the rat olfactory receptor gene family. J Mol Evol 36:249-254

Keverne EB (1999) The vomeronasal organ. Science 286:716-720

Kim UK, Jorgenson E, Coon H, Leppert M, Risch N, Drayna D (2003) Positional cloning of the human quantitative trait locus underlying taste sensitivity to phenylthiocarbamide. Science 299:1221-1225

Kim UK, Wooding S, Ricci D, Jorde LB, Drayna D (2005) Worldwide haplotype diversity and coding sequence variation at human bitter taste receptor loci. Hum Mutat 26:199-204

Kim UK, Wooding S, Riaz N, Jorde LB, Drayna D (2006) Variation in the human TAS1R taste receptor genes. Chem Senses 31:599-611

Kimoto H, Haga S, Sato K, Touhara K (2005) Sex-specific peptides from exocrine glands stimulate mouse vomeronasal sensory neurons. Nature 437:898-901

Kinnamon SC, Margolskee RF (1996) Mechanisms of taste transduction. Curr Opin Neurobiol 6:506-513

Kitagawa M, Kusakabe Y, Miura H, Ninomiya Y, Hino A (2001) Molecular genetic identification of a candidate receptor gene for sweet taste. Biochem Biophys Res Commun 283:236-242

Lane RP, Young J, Newman T, Trask BJ (2004) Species specificity in rodent pheromone receptor repertoires. Genome Res 14:603-608

Li X, Staszewski L, Xu H, Durick K, Zoller M, Adler E (2002) Human receptors for sweet and umami taste. Proc Natl Acad Sci USA 99:4692-4696

Li X, Li W, Wang H, Cao J, Maehashi K, Huang L, Bachmanov AA, Reed DR, Legrand-Defretin V, Beauchamp GK, Brand JG (2005) Pseudogenization of a sweet-receptor gene accounts for cats' indifference toward sugar. PLoS Genet 1:e3

Liberles SD, Buck LB (2006) A second class of chemosensory receptors in the olfactory epithelium. Nature 442:645-650

Liman ER, Innan H (2003) Relaxed selective pressure on an essential component of pheromone transduction in primate evolution. Proc Natl Acad Sci USA 100:3328-3332

Lindemann B (2001) Receptors and transduction in taste. Nature 413:219-225

Loconto J, Papes F, Chang E, Stowers L, Jones EP, Takada T, Kumanovics A, Fischer Lindahl K, Dulac C (2003) Functional expression of murine V2R pheromone receptors involves selective association with the M10 and M1 families of MHC class Ib molecules. Cell 112:607-618

Malnic B, Godfrey PA, Buck LB (2004) The human olfactory receptor gene family. Proc Natl Acad Sci USA 101:2584-2589

Matsunami H, Buck LB (1997) A multigene family encoding a diverse array of putative pheromone receptors in mammals. Cell 90:775-784

Matsunami H, Montmayeur JP, Buck LB (2000) A family of candidate taste receptors in human and mouse. Nature 404:601-604 
Max M, Shanker YG, Huang L, Rong M, Liu Z, Campagne F, Weinstein H, Damak S, Margolskee RF (2001) Tas1r3, encoding a new candidate taste receptor, is allelic to the sweet responsiveness locus Sac. Nat Genet 28:58-63

Menashe I, Man O, Lancet D, Gilad Y (2003) Different noses for different people. Nat Genet 34:143-144

Meyerhof W (2005) Elucidation of mammalian bitter taste. Rev Physiol Biochem Pharmacol 154:37-72

Mombaerts P (1999) Molecular biology of odorant receptors in vertebrates. Annu Rev Neurosci 22:487-509

Mombaerts P (2004) Genes and ligands for odorant, vomeronasal and taste receptors. Nat Rev Neurosci 5:263-278

Montmayeur JP, Liberles SD, Matsunami H, Buck LB (2001) A candidate taste receptor gene near a sweet taste locus. Nat Neurosci 4:492-498

Mundy NI, Cook S (2003) Positive selection during the diversification of class I vomeronasal receptor-like (V1RL) genes, putative pheromone receptor genes, in human and primate evolution. Mol Biol Evol 20:1805-1810

Nei M (2007) The new mutation theory of phenotypic evolution. Proc Natl Acad Sci USA 104:12235-12242

Nei M, Gu X, Sitnikova T (1997) Evolution by the birth-and-death process in multigene families of the vertebrate immune system. Proc Natl Acad Sci USA 94:7799-7806

Nelson G, Hoon MA, Chandrashekar J, Zhang Y, Ryba NJ, Zuker CS (2001) Mammalian sweet taste receptors. Cell 106:381-390

Niimura Y, Nei M (2003) Evolution of olfactory receptor genes in the human genome. Proc Natl Acad Sci USA 100:12235-12240

Niimura Y, Nei M (2005) Evolutionary dynamics of olfactory receptor genes in fishes and tetrapods. Proc Natl Acad Sci USA 102:6039-6044

Niimura Y, Nei M (2006) Evolutionary dynamics of olfactory and other chemosensory receptor genes in vertebrates. J Hum Genet 51:505-517

Niimura Y, Nei M (2007) Extensive gains and losses of olfactory receptor genes in Mammalian evolution. PLoS ONE 2:e708

Nozawa M, Kawahara Y, Nei M (2007) Genomic drift and copy number variation of sensory receptor genes in humans. Proc Natl Acad Sci USA 104:20421-20426

Parry CM, Erkner A, le Coutre J (2004) Divergence of T2R chemosensory receptor families in humans, bonobos, and chimpanzees. Proc Natl Acad Sci USA 101:14830-14834

Pfister P, Rodriguez I (2005) Olfactory expression of a single and highly variable V1r pheromone receptor-like gene in fish species. Proc Natl Acad Sci USA 102:5489-5494

Pfister P, Randall J, Montoya-Burgos JI, Rodriguez I (2007) Divergent evolution among teleost V1r receptor genes. PLoS ONE 2:e379

Prasad BC, Reed RR (1999) Chemosensation: molecular mechanisms in worms and mammals. Trends Genet 15:150-153

Rodriguez I, Mombaerts P (2002) Novel human vomeronasal receptor-like genes reveal speciesspecific families. Curr Biol 12:R409-411

Rodriguez I, Del Punta K, Rothman A, Ishii T, Mombaerts P (2002) Multiple new and isolated families within the mouse superfamily of V1r vomeronasal receptors. Nat Neurosci 5:134-140

Rouquier S, Blancher A, Giorgi D (2000) The olfactory receptor gene repertoire in primates and mouse: evidence for reduction of the functional fraction in primates. Proc Natl Acad Sci USA 97:2870-2874

Ryba NJ, Tirindelli R (1997) A new multigene family of putative pheromone receptors. Neuron 19:371-379

Sainz E, Korley JN, Battey JF, Sullivan SL (2001) Identification of a novel member of the T1R family of putative taste receptors. J Neurochem 77:896-903

Saraiva LR, Korsching SI (2007) A novel olfactory receptor gene family in teleost fish. Genome Res 17:1448-1457 
Shi P, Zhang J (2006) Contrasting modes of evolution between vertebrate sweet/umami receptor genes and bitter receptor genes. Mol Biol Evol 23:292-300

Shi P, Zhang J (2007) Comparative genomic analysis identifies an evolutionary shift of vomeronasal receptor gene repertoires in the vertebrate transition from water to land. Genome Res 17:166-174

Shi P, Zhang J, Yang H, Zhang YP (2003) Adaptive diversification of bitter taste receptor genes in mammalian evolution. Mol Biol Evol 20:805-814

Shi P, Bielawski JP, Yang H, Zhang YP (2005) Adaptive diversification of vomeronasal receptor 1 genes in rodents. J Mol Evol 60:566-576

Smith CUM (2000) Biology of sensory systems. Wiley, New York

Soranzo N, Bufe B, Sabeti PC, Wilson JF, Weale ME, Marguerie R, Meyerhof W, Goldstein DB (2005) Positive selection on a high-sensitivity allele of the human bitter-taste receptor TAS2R16. Curr Biol 15:1257-1265

Tacher S, Quignon P, Rimbault M, Dreano S, Andre C, Galibert F. (2005) Olfactory receptor sequence polymorphism within and between breeds of dogs. J Hered 96: 812-816

Trask BJ, Friedman C, Martin-Gallardo A, Rowen L, Akinbami C, Blankenship J, Collins C, Giorgi D, Iadonato S, Johnson F, Kuo WL, Massa H, Morrish T, Naylor S, Nguyen OT, Rouquier S, Smith T, Wong DJ, Youngblom J, van den Engh G. (1998) Members of the olfactory receptor gene family are contained in large blocks of DNA duplicated polymorphically near the ends of human chromosomes. Hum Mol Genet 7: 13-26

Wang X, Thomas SD, Zhang J. (2004) Relaxation of selective constraint and loss of function in the evolution of human bitter taste receptor genes. Hum Mol Genet 13: 2671-2678

Wong KK, deLeeuw RJ, Dosanjh NS, Kimm LR, Cheng Z, Horsman DE, MacAulay C, Ng RT, Brown CJ, Eichler EE, Lam WL. (2007) A comprehensive analysis of common copy-number variations in the human genome. Am J Hum Genet 80: 91-104

Wooding S, Kim UK, Bamshad MJ, Larsen J, Jorde LB, Drayna D. (2004) Natural selection and molecular evolution in PTC, a bitter-taste receptor gene. Am J Hum Genet 74: 637-646

Wooding S, Bufe B, Grassi C, Howard MT, Stone AC, Vazquez M, Dunn DM, Meyerhof W, Weiss RB, Bamshad MJ. (2006) Independent evolution of bitter-taste sensitivity in humans and chimpanzees. Nature 440: 930-934

Yang H, Shi P, Zhang YP, Zhang JZ. (2005) Composition and evolution of the V2r vorneronasal receptor gene repertoire in mice and rats. Genomics 86: 306-315

Young JM, Trask BJ. (2002) The sense of smell: genomics of vertebrate odorant receptors. Human Molecular Genetics 11: 1153-1160

Young JM, Trask BJ. (2007) V2R gene families degenerated in primates, dog and cow, but expanded in opossum. Trends Genet 23: 212-215

Young JM, Kambere M, Trask BJ, Lane RP. (2005) Divergent V1R repertoires in five species: Amplification in rodents, decimation in primates, and a surprisingly small repertoire in dogs. Genome Res 15: 231-240

Zhang J. (2003) Evolution by gene duplication: an update. Trends Ecol Evol 18: 292-298

Zhang J. (2007) The drifting human genome. Proc Natl Acad Sci U S A 104: 20147-20148

Zhang J, Webb DM. (2003) Evolutionary deterioration of the vomeronasal pheromone transduction pathway in catarrhine primates. Proc Natl Acad Sci U S A 100: 8337-8341

Zhang X, Rodriguez I, Mombaerts P, Firestein S. (2004) Odorant and vomeronasal receptor genes in two mouse genome assemblies. Genomics 83: 802-811

Zhang X, Zhang X, Firestein S. (2007) Comparative genomics of odorant and pheromone receptor genes in rodents. Genomics 89: 441-450

Zhao GQ, Zhang Y, Hoon MA, Chandrashekar J, Erlenbach I, Ryba NJ, Zuker CS. (2003) The receptors for mammalian sweet and umami taste. Cell 115: 255-266

Zozulya S, Echeverri F, Nguyen T. (2001) The human olfactory receptor repertoire. Genome Biol 2: RESEARCH0018 